\title{
Willingness to Share Knowledge Compared with Selected Social Psychology Theories
}

\author{
Ewa Krok
}

ABSTRACT

Knowledge is one of the key determinants in the growth and competitiveness of modern enterprises. Hence, it is essential to analyse the factors that induce employees to exchange knowledge. The problem of sharing an intangible asset — in this case, the knowledge of individuals — can be viewed from many perspectives: psychological, economic, organisational, sociological and technological.

The aim of this article is to explore selected social psychology theories and to analyse the incentives for people to share knowledge.

The article attempts to interpret the willingness to share knowledge through the Social Exchange Theory, the Social Impact Theory, the Theory of Reasoned Action and the Theory of Planned Behaviour. This analysis leads to the following conclusions:

- we share our knowledge and expect a return;

- we share our knowledge when we believe that the benefits of this action outweigh the costs;

- we are pushed to share knowledge by the power of empathy;

- workers' willingness to share knowledge is influenced by three social processes: subordination, identification and internalisation;

- the decision to share knowledge is preceded by an intention formed under the influence of an individual attitude towards that behaviour, subjective norms and perceived behavioural control; and

- the decision to share knowledge is also influenced by additional components, including the knowledge and skills to implement this behaviour, environmental limitations, behavioural emphasis and habits.

KEY WORDS: $\quad$ knowledge sharing, willingness to share knowledge, social psychology theories

JEL Classification: $\quad$ A12, M50

${ }^{1}$ Szczecin University, POLAND

\section{Introduction}

Because of the importance of knowledge for the development and competitiveness of enterprises in the information age, knowledge management theoreticians and practitioners analyse sharing this strategic, nonmaterial commodity from numerous perspectives, trying to identify both the barriers to and factors favouring knowledge exchange.

믐

Correspondence concerning this article should be addressed to: Ewa Krok, Szczecin University, 64 Mickiewicza Str., 71-101 Szczecin, POLAND, e-mail: ewakrok@wp.pl
The variety of determinants of knowledge sharing make it very difficult to find one universal model that presents this problem from various perspectives, such as psychological, business, organisational, sociological and technological.

The aim of the article is to analyse people's (employees') knowledge-sharing inclination by examining the influence of psychological factors.

Knowledge sharing will be considered in light of selected social psychology theories. The author concentrates primarily on analysing how the presence and activities of other people affect an individual's psyche 
and determines his or her behaviour. Knowledge sharing is a social situation in which one's emotions, attitudes, and consequently, actions, are influenced by other people, both consciously and unconsciously.

In addition, the author also analyses the Process Theories of Motivation because motivation, particularly extrinsic motivation, is one of the factors that determines the knowledge-sharing process and is largely shaped by environmental influences.

By selecting and reviewing the most essential psychological theories that address the formation of human attitudes and behaviours connected with knowledge sharing, the author's considerations will be synthesised. This, in turn, will facilitate the transition of the considered theories and research findings into practice, which is a powerful challenge for those responsible for human resource management in organisations.

\section{Sociobiology}

The motivation behind knowledge sharing can be explained by Sociobiology, a scientific discipline that aims to explain all forms of social behaviour in both animals and people by examining those behaviours in the context of the Theory of Organic Evolution formulated by Charles Darwin. Sociobiology assumes that the source of social behaviour is in the genes and that types of behaviour evolve because of environmental influences. Edward Osborne Wilson, an American biologist and zoologist, is regarded as the creator of contemporary Sociobiology. Recently, Richard Dawkins has become one of the main promoters and popularisers of Sociobiology.

According to this theory, sharing certain goods with individuals genetically similar to us is an instinctive reaction. However, the motivation for knowledge sharing cannot be explained exclusively by the notion of kin selection. It explains a willingness to help - in this case, making knowledge available to those who will transfer our genes to the next generations - but it does not justify mutual knowledge sharing by total strangers. Therefore, sociobiologists indicate the existence of a genetically determined reciprocity standard that is important for a species to survive (Aronson, Wilson, \& Akert, 1997). We assume that others will treat us in the same way that we treat them. If we share our knowledge with someone, we expect him or her to repay us with the same in the future.

\section{The Social Exchange Theory}

However, many psychologists do not agree with the sociobiological position. They refer to one of the most important social psychology theories, the Social Exchange Theory. According to this theory, our actions are motivated by the desire to maximise profit and minimise costs, and basic human nature is being concerned about our own interests. Therefore, in social relations, we attempt to maximise the ratio of profits to costs (Dovidio et al., 1991; Smith, Keating, \& Stotland, 1989). Every situation in which we share knowledge entails certain profits and losses. One should consider three cases in which knowledge sharing can be rewarding. First, there is the reciprocity standard that was mentioned before. We act how we want others to act towards us, or we share our knowledge counting on reciprocity. Second, when we help someone by making our knowledge available to him or her, we also relieve a certain discomfort connected with watching someone struggle to perform a task (e.g., we feel better because we did something appropriate). Third, knowledge sharing can yield recognition (e.g., others think positively about us) or different types of material rewards (e.g., a promotion or a higher salary).

According to the Social Exchange Theory, there is no altruism, which is defined as acting to benefit others without considering one's own interest. La Rochefoucauld (2010) in his maxims notes, that what seems like generosity is often nothing else but a concealed ambition.

People will share their knowledge only when it is in their interest, i.e., when expected profits will exceed costs. Therefore, workers' motivation to share knowledge decreases when the costs are high and increases when the profits are high.

\section{Empathy and altruism}

However, evidence to support the hypothesis about the existence of true altruism is provided by the research by Batson (1991). The research concerned the reasons for helping other people selflessly. According to the results, it can be assumed that a worker will share his or her knowledge for motives other than sheer ego, provided that he or she feels empathy towards the knowledge recipient. Empathy will be elicited much more by a person who seems similar to us in some way, such as holding similar values or having similar interests and experience. 

the expected reward and when he expects that the achievement of the goal will be followed by the expected consequence.

If $\mathrm{Mr} \mathrm{X}$, in considering his and his colleagues' possibilities, estimates that the probability of becoming the person to make the highest number of entries as very low, he will not make much effort. He will behave similarly if the consequences of becoming the best employee (with respect to entries in the Intranet) do not meet his expectation, that is, receiving a bonus would not satisfy him (because, for instance, he would prefer to be recognised in another way).

The following is another example of the Expectancy-Value Theory: an employee is supposed to provide other employees with knowledge that he gained during a training session. His superior did not define either the form or the manner of the knowledge transfer. However, if the employee sees fulfilment of the task given by his superior as the only consequence of his action, he will not make much effort, and the knowledge transfer could occur in the course of a short meeting held on short notice during which the employee would discuss the training briefly. However, if the employee cares about his colleagues' opinion and simultaneously estimates that the probability of increasing his reputation in their eyes is high, then he will devote quite a long time to prepare a rich presentation and will put a lot of effort into leading the meeting so that the participants will leave satisfied. If the employee cares about his colleagues' opinion but does not see any opportunities to meet their expectations, and he estimates that the probability of them leaving satisfied is low, then his effort will be rather small.

The Expectancy-Value Theory of motivation may provide a useful theoretical foundation for understanding the perceptions of knowledge shareability and their relationship to actual knowledge sharing. Boughzala and Briggs (2012) define knowledge shareability as an attitude and knowledge sharing as a behaviour, and to explain the differences between them, they propose a Value Frequency Model of Knowledge Sharing (VFMKS). These two constructs are very important because knowledge shareability attitudes may impact knowledge sharing behaviours. Knowledge sharing behaviours are significant in interdisciplinary cooperation among groups and organisations, which are becoming more frequent. It causes situations in which the cooperating employees must make decisions about knowledge sharing, especially hidden knowledge, if the collaboration is to help achieve the goals set by both of the organisations.

The Process Theories of Motivation include the Equity Theory developed by Adams (1965). It is based on the assumption that people strive for an equitable division of the rewards obtained in connection with their achievements at work. This fair division is understood as a ratio of the amount of labour the employee exerts to the rewards obtained by him compared with the rewards given to others for similar efforts. Employees prefer a balance in which they perceive their rewards as comparable to those of co-workers who exert the same amount of effort (Adams, Berkowitz, \& Hatfield, 1976).

Therefore, if the applied incentives are supposed to motivate employees, they must be perceived as reliable, fair and comparable with the incentives that are received by the employees' peers.

The Process Theories of Motivation also include the Goal-Setting Theory developed by Locke (1968), which is valued by experts as a very useful incentive tool. The basic assumption of this theory is that intentions expressed as goals are huge motivators. The inclination to work towards achieving goals that satisfy employees' needs is the most effective source of motivation. The decision-making process that occurs between the organisation and the employee results in setting specific goals for the employee, and the realisation of those goals at the level required by the organisation influences the employee's reward and satisfaction of his/her needs. Among the basic factors that determine the efficiency of the motivation process based on Locke's concept are the degree of participation by the employee in the goal-setting process, the employee's acceptance level, and the difficulty and specificity of the goal. The goals that are set with employee input tend to be more accepted. The research has also shown that in the motivation process, specific and difficult goals are better than goals that do not require much effort or goals that are too exorbitant.

The employee will be motivated to share knowledge if conversations with his/her superior result in a specific goal that the employee believes is feasible. For example, an employee is supposed to transfer specialized knowledge to three collaborators from his/her department within a week. The employee has to train the collabora- 


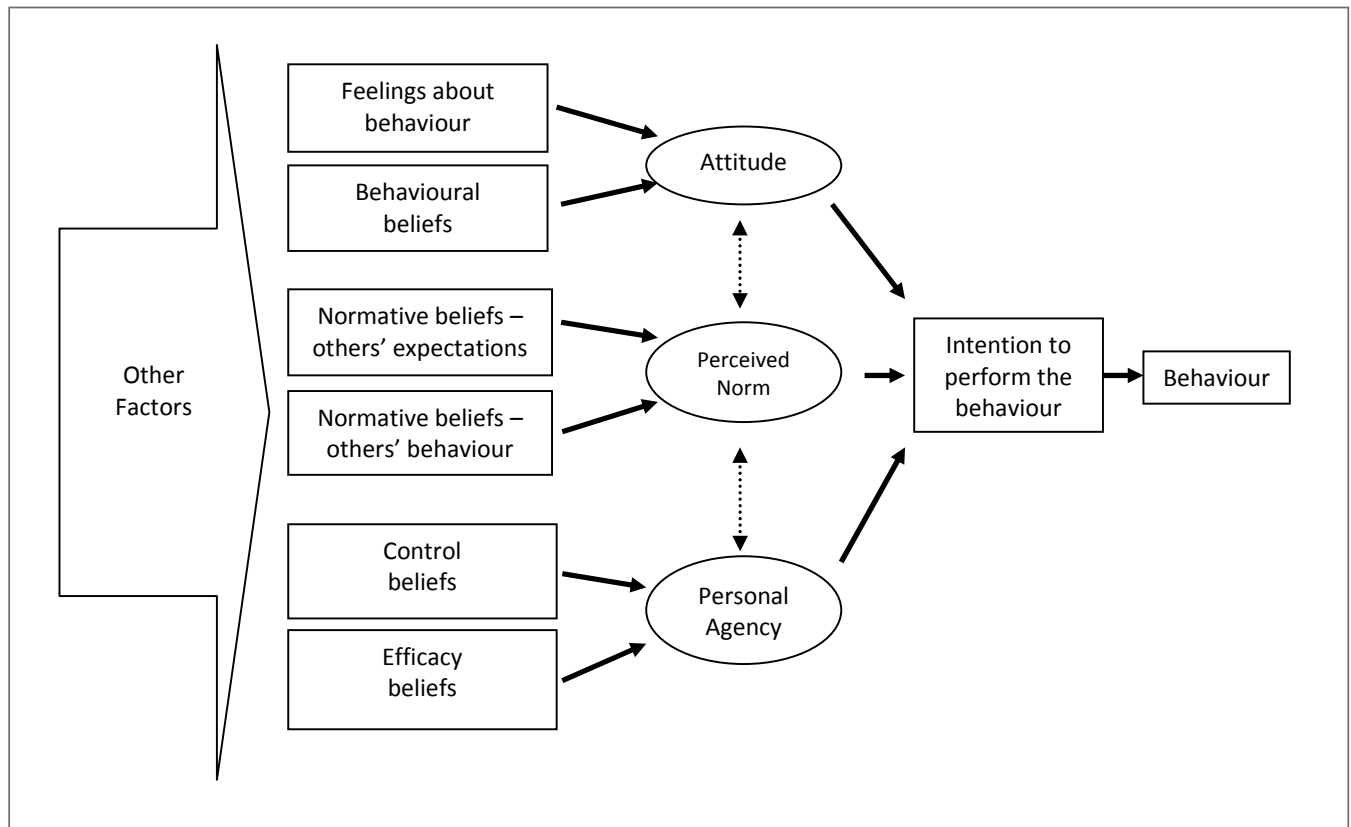

Figure 1. Theory of Planned Behaviour (Montaño \& Kasprzyk, 2008).

tors so that they can do a task that requires this knowledge themselves. If the employee develops a strategy for sharing this knowledge, knows his/her colleagues' skills, and the period of one week seems feasible, he/she could be expected to be willing to undertake this task. Determining a satisfying and fair reward for the knowledge transfer with his/her superior would augment the employee's willingness to share the knowledge.

Incentives, regardless of their nature, are not the only factors that determine whether knowledge sharing occurs.

\section{The Social Impact Theory}

The Social Impact Theory is one of the group behaviour theories that can also be considered in the analysis of the willingness to share knowledge. Workers of a given organisation are members of a group or team with a common interest: the completion of assigned tasks that involve interaction and mutual communication.

Kelman (1958) maintains that the individual behaviour of a group member is determined by three social processes:

- subordination - activities are undertaken because of a positive reaction from people important to a worker. "I share knowledge because I know that my superior will take this into consideration in my annual appraisal".

- identification - a worker needs to identify with the group and seeks a sense of belonging. "I share knowledge because I can see that others do, and I do not want to be rejected by them".

- internalisation - a worker is motivated to perform in a certain way because it conforms to his or her value system. "I share knowledge because I think it is what one ought to do".

\section{The Theory of Reasoned Action and the Theory of Planned Behaviour}

Another behaviour model worth investigating in the context of knowledge sharing is the Theory of Reasoned Action (TRA), by Fishbein and Ajzen's (1975), and its expanded version, the Theory of Planned Behaviour (TPB). They are the bases for many models of decision making.

According to the Theory of Planned Behaviour, every behaviour is preceded by a deliberate intention to make something. It is shaped by the individual's attitude towards that behaviour, a subjective norm and a perceived behavioural control. 
Every behaviour creates certain results. Each of those results has a certain value for a decision maker and an estimated probability of occurrence. In the literature, this estimation of the chances of a determined result occurring connected with undertaking an activity is referred to as behavioural beliefs. The attitude towards behaviour is defined as a sum of products of the value and the probability of the appearance of results.

The subjective norm is an individual's belief about whether and how his or her activities will be accepted by the people important to him or her. The power of an individual's belief about how much a particular person wants to exert influence on him or her is referred to as normative beliefs. How much a person wants to submit to people important to him or her is called a motivation to perform a task.

Perceived behavioural control is the level of control an individual has over a certain behaviour. The estimation of the chances that there will be particular problems with undertaking an activity is called control beliefs. The belief about one's ability to overcome these problems is called personal agency.

Given the approaches to the issue of knowledge sharing, which substantially consider psychological factors, it seems that the model of the Theory of Planned Behaviour would successfully be applied in the empirical research of this problem.

To illustrate the assumptions of the Theory of Planned Behaviour in the research, one can introduce the following theoretical example of the reasoning of a person who is considering sharing his or her knowledge:

- the attitude of such a person will be a consequence of his or her estimating the chances that sharing knowledge will bring determined results (e.g., an increase in pay, recognition from collaborators, satisfaction from being an expert, being used by collaborators, becoming redundant) and a positive or negative assessment of these results.

- the perceived (subjective) norm is a consequence of workers' estimating the pressure exerted on them by people nearby, e.g., by the manager, regarding sharing knowledge and their willingness to submit to that pressure. If we want to satisfy someone, we will do something against our regular attitudes. Therefore, the subjective norm refers to the social control mechanism. The worker as a team member exchanges mutual incentives that are a source of reward and punishment for him or her. These incentives strengthen his or her behaviour.

- personal agency (perceived behavioural control) results from the power of a worker's belief about the fact that a determined problem or obstacle can appear on the way to making a final decision about knowledge sharing and a subjective assessment of his or her ability to overcome that problem or obstacle.

It is worth mentioning that the attitude, the subjective norm and the perceived behavioural control can influence one another. Therefore, increasing the amount of control that the worker feels about knowledge sharing can result in a more positive attitude towards undertaking such behaviour.

It should also be stressed that both the TRA and TPB are used for anticipating planned, deliberate human behaviour rather than spontaneous behaviour that occurs as a result of, for example, a sudden external factor. These theories also assume that an intention to undertake a specific action - in this case, sharing knowledge - is influenced first of all by subjective and psychological behavioural factors.

Kolekovski and Heminger (2003) introduced this model into the research of the determinants of knowledge sharing, and they discovered potentially essential beliefs that seem to significantly influence knowledge exchange in organisations. Workers make their decisions about whether to share knowledge, depending on the following:

- their beliefs about knowledge (recognising knowledge as a personal interest or belonging to an organisation; perceived resources and values of knowledge)

- their beliefs about interpersonal relations (the power and the type of relationship that links them with a person with whom they would like to share their knowledge; a fear of being misled by improper knowledge sharing; expectations of reciprocity, or a belief that others will act similarly, i.e., they will also share their knowledge)

- their beliefs about the organisation (assessment of organisational norms concerning knowledge sharing and engagement in knowledge exchange)

- their beliefs about tasks (assessment of the degree to which the knowledge is relevant and essential for the realisation of a given task). 
Hypotheses concerning these beliefs as the determinants of workers' willingness to share knowledge were confirmed by Kolekovski and Heminger (2003) in their practical research. Therefore, it seems advisable to consider these factors when building tools for evaluating the motivation for knowledge sharing.

Recently, the authors of the TRA and TPB widened the conceptions, taking into account components from other essential behavioural theories and proposed the so-called Integrated Behavioural Model, or IBM (Montaño \& Kasprzyk, 2008). Those additional elements directly affecting behaviour are the following:

- the knowledge and skills essential for the behavioural realisation.

- "limitations from the environment" that can make it very difficult or impossible to realise behaviour

- the relevance of the realisation of behaviour for a given person

- an earlier occurrence of a similar type of behaviour For example, if a worker intends to share his or her knowledge, it is essential that he or she also possesses the technical skills for the execution of this task, e.g., making a presentation, preparing directions or certain didactic competencies. Another issue is possible environmental obstacles, that is, providing him or her with suitable organisational conditions in the firm (a room, elimination of noise) and a lack of time pressure. One should also make the knowledge-sharing behaviour very important for the worker and inspire him or her to carry out his or her intention. The chance that the worker engages in knowledge-sharing behaviour increases if he or she has already done so.

\section{Conclusion}

The issue of workers' willingness to share knowledge requires the investigation of many factors. Factors that determine workers' commitment to the knowledge exchange process can depend both on the worker as an individual, his or her personality, age, sex, education, position and many other attributes, but also on the organisation, its internal conditions and interpersonal relations, its management style and organisational culture, and on the knowledge itself, its value, type, and ways of conveying it.

The identification of these factors is essential to analysing particular organisations. Such factors are, among other things, a basis for undertaking activities that lead to the increase in knowledge exchange among workers.

This article presented only several approaches to the interpretation of the willingness to share knowledge, namely

- education in the process of the genetic development of the reciprocity standard that makes us share our knowledge, counting on a return

- knowledge sharing is a manifestation of taking care of oneself (profits from knowledge sharing exceed the costs)

- in certain circumstances, we are urged to share our knowledge by empathy towards a given person

- workers' willingness to share knowledge depends on its being influenced by three social processes: subordination, identification and internalisation

- intentions and decisions made on the basis of these processes, connected with knowledge sharing, are shaped in compliance with the Theory of Planned Behaviour, i.e., first of all influenced by an individual's attitude towards that behaviour, the subjective norm and the perceived behavioural control

- behaviour, according to the integrated behavioural model, is also influenced by additional elements: the knowledge and skills to engage in the behaviour, limitations of the environment, and emphasising the behaviour and habits.

The analysis of the knowledge-sharing inclination in the context of the Process Theories of Motivation showed that:

- knowledge sharing motivation depends on how high the probability of fulfilling our expectations is;

- if something is to motivate employees to share knowledge, it must be perceived by them as reliable and fair;

- the basic factors that influence the efficiency of the motivation process include the degree of the employee's participation in the goal-setting process, the acceptance level, and the difficulty of the specific goal.

Certainly, the analysis of the willingness to share knowledge requires a separate discussion in the context of other contemporary motivational conceptions: the theories of needs (Maslow, 1954; McClelland, 1987) and reinforcement (Kozioł, Piechnik-Kurdziel, \& Kopeć, 2000; Bandura, 2007; Zimbardo, 2011).

Another interesting issue may be the assessment of the influence of technology on workers' willingness 
to share knowledge, which can be done by considering the Technology Acceptance Model - TAM (Davis, Bagozzi, \& Warshaw, 1989; Venkatesh \& Davis, 2000; Venkatesh et al., 2003) - or the Theory of Adjusting Technology to a Task (Goodhue \& Thompson, 1995).

\section{References}

Adams, J. S., Berkowitz, L., \& Hatfield, E. (1976). Equity theory: toward a general theory of social interaction. New York, NY: Academic Press.

Adams, J. S. (1965). Inequity in Social Exchanges. In L. Berkwitz (Eds.), Advances in experimental social psychology (pp. 267-300). New York, NY: Academic Press.

Aronson, E., Wilson, T. D., \& Akert, R. M. (1997). Psychologia społeczna. Serce $i$ umyst [Social psychology. The heart and the mind]. Poznań: Zysk i S-ka.

Bandura, A. (2007). Teoria społecznego uczenia się [Social learning theory]. Warszawa: PWN.

Batson, C. D. (1991). The altruism question: toward a social-psychological answer. Hillsdale, NJ: Lawrence Erlbaum Associates.

Berkowitz, L. (1987). Mood, self-awareness, and willingness to help. Journal of Personality and Social Psychology, 52(4), 721-729.

Boughzala, I., \& Briggs, R. O. (2012). A value frequency model of knowledge sharing: an exploratory study on knowledge sharability in cross-organizational collaboration. Electronic Markets 22(1), 9-19.

Carlson, M., Charlin, V., \& Miller, N. (1988). Positive mood and helping behavior: A test of six hypotheses. Journal of Personality and Social Psychology, 55(2), 211-229.

Cialdini, R. B., Darby, B. L., \& Vincent, J. E. (1973). Transgression and altruism: a case for hedonism. Journal of Experimental Social Psychology, 9(6), 502-516.

Cialdini, R. B., \& Fultz, J. (1990). Interpreting the negative mood-helping literature via "mega"- analysis: a contrary view. Psychological Bulletin, 107(2), 210-214.

Darley, J. M., \& Batson, C. D. (1973). From Jerusalem to Jericho: a study of situational and dispositional variables in helping behavior. Journal of Personality and Social Psychology, 27(1), 100-108.

Davis, F. D., Bagozzi, R. P., \& Warshaw, P. R. (1989). User acceptance of computer technology: a com- parison of two theoretical models. Management Science, 35(8), 982-1002.

Dovidio, J. F., Piliavin, J. A., Gaertner, S. L, Schroeder, D. A., \& Clark, R. D. (1991). The arousal: cost-reward model and the process of intervention. In M. S. Clark (Ed.), Review of personality and social psychology, (Vol. 12, pp. 86-118). Newbury Park, CA: Sage.

Fishbein, M., \& Ajzen, I. (1975). Belief, attitude, intention and behaviour: an introduction to theory and research. Reading, MA: Addison-Wesley.

Goodhue, D. L., \& Thompson, R. L. (1995). Task-technology fit and individual performance. MIS Quarterly, 19(2), 213-236.

Kelman, H. C. (1958). Compliance, identification and internalisation. Three processes of attitude change. Journal of Conflict Resolution, 2(1), 51-60.

Kolekovski, K. E., \& Heminger, A. R. (2003). Beliefs and attitudes affecting intentions to share information in an organizational setting. Information and Management, 40(6), 521-532.

Kozioł, L., Piechnik-Kurdziel, A., \& Kopeć, J. (2000). Zarzadzanie zasobami ludzkimi w firmie. Teoria i praktyka [Human resource management in a company. Theory and practice]. Warszawa: Biblioteczka Pracownicza.

La Rochefoucauld, F. (2010). Maxims and moral reflections. Kęty: Wydawnictwo Marek Derewiecki.

Locke, E. A. (1968). Toward a Theory of Task Motivation and Incentives. Organizational behavior and human performance, (3)2, 157-189.

Maslow, A. H. (1954). Motivation and Personality. New York, NY: Harper \& Brothers.

McClelland, D. C. (1987). Human motivation. Cambridge, UK: Cambridge University Press.

Montaño, D. E., \& Kasprzyk, D. (2008). Theory of reasoned action, theory of planned behavior and the integrated behavioral model. In K. Glanz, B. K. Rimers, \& K. Viswanath (Eds.), Health behavior and health education: theory, research and practice (pp. 67-96). San Francisco, CA: Jossey-Bass.

Porter, L. W., \& Lawler, E. E. (1968). Managerial attitudes and performance. Homewood, IL: Richard D. Irwin.

Smith, K. D., Keating, J. P., \& Stotland, E. (1989). Altruism reconsidered: the effect of denying feedback on victim's status to empathic witnesses. Journal of Personality and Social Psychology, 57(4), 641-650. 
Van Aken, T., Camps, T., \& Jurgens, B. (1997). Organiseren van denkwerk: return on thinking [Organizing thinking: return on thinking]. Assen: Van Gorcum.

Venkatesh, V., \& Davis, F. D. (2000). A theoretical extension of the technology acceptance model: four longitudinal field studies. Management Science, 46(2), 186-204.

Venkatesh, V., Morris, M. G., Davis, G. B., \& Davis, F. D. (2003). User acceptance of information technology: toward a unified view. MIS Quarterly, 27(3), 425-478.

Vroom, V. H. (1964). Work and motivation. New York, NY: Wiley.

Zimbardo, P. (2011). Kluczowe koncepcje - tom 2. Motywacja i uczenie się [Core concepts - Vol. 2. Motivation and learning]. Warszawa: PWN. 